\title{
Antioxidant, hemolytic, antimicrobial, and cytotoxic activities of the tropical Atlantic marine zoanthid Palythoa caribaeorum
}

\author{
DANIEL B. ALENCAR ${ }^{1}$, ARTHUR A. MELO ${ }^{1}$, GISELLE C. SILVA ${ }^{2}$, REBECA L. LIMA ${ }^{1}$, \\ KELMA M.S. PIRES-CAVALCANTE ${ }^{1}$, RÔMULO F. CARNEIRO ${ }^{1}$, ADRIANA S. RABELO ${ }^{1}$, \\ OSCARINA V. SOUSA ${ }^{2}$, REGINE H.S.F. VIEIRA ${ }^{2}$, FRANCISCO A. VIANA ${ }^{3}$, \\ ALEXANDRE H. SAMPAIO ${ }^{1}$ and SILVANA SAKER-SAMPAIO ${ }^{1}$ \\ ${ }^{1}$ Departamento de Engenharia de Pesca, Universidade Federal do Ceará, Campus do Pici, \\ Av. Mister Hull, s/n, Caixa Postal 6043, 60455-970 Fortaleza, CE, Brasil \\ ${ }^{2}$ Instituto de Ciências do Mar, Universidade Federal do Ceará, \\ Av. da Abolição, 3207, 60165-081 Fortaleza, CE, Brasil \\ ${ }^{3}$ Departamento de Química, Universidade do Estado do Rio Grande do Norte, Campus Universitário \\ Central, Setor III, Rua Prof. Antônio Campos, s/n, 59633-010 Mossoró, RN, Brasil
}

Manuscript received on July 16, 2014; accepted for publication on November 25, 2014

\begin{abstract}
Marine invertebrates are capable of synthesizing bioactive compounds, which may be beneficial to human health. The aim of this study was to evaluate the antioxidant, hemolytic, antimicrobial and cytotoxic activities of crude extract (70\% EtOH), and dichloromethane (DCM), ethyl acetate (EtOAc), and aqueous (Aq) fractions of the marine zoanthid Palythoa caribaeorum. The phenolic compound contents of the crude extract, DCM, EtOAc and Aq fractions were 12.33, 18.17, 10.53, and $3.18 \mathrm{mg}$ GAE per gram, respectively. DPPH radical scavenging activity showed slight variation. $\mathrm{IC}_{50}$ of crude extract, $\mathrm{DCM}$, EtOAc and Aq fractions were 11.13, 11.25, 11.74, and $11.28 \mu \mathrm{g} \mathrm{mL}^{-1}$, respectively. Among the sample, ferrous ion chelating was the highest in crude extract $\left(\mathrm{IC}_{50} 302.90 \mu \mathrm{g} \mathrm{mL}^{-1}\right)$, followed by EtOAc, Aq, and DCM fractions with 457.77, 547.91, and $641.82 \mu \mathrm{g} \mathrm{mL}^{-1}$, respectively. Ferric-reducing antioxidant power showed optical density at about 0.5 . The samples tested exhibited low hemolytic activity under $10 \%$ up to a concentration of $50 \mu \mathrm{g} \mathrm{mL}^{-1}$. No antimicrobial activity was observed against any of the tested bacterial strains. For the cytotoxic activity, $\mathrm{LC}_{50}$ of DCM, crude extract, EtOAc, and Aq were 52.10, 83.06, 86.34, and $117.45 \mu \mathrm{g} \mathrm{mL}^{-1}$, showing high toxicity.
\end{abstract}

Key words: biological activity, marine invertebrate, natural product, Sphenopidae.

\section{INTRODUCTION}

In recent decades, the discovery of new substances isolated from marine organisms has increased. These substances may be biologically active and may have well-defined biological properties, e.g.,

Correspondence to: Daniel Barroso de Alencar

E-mail: daniellpesca@gmail.com antitumor, anti-inflammatory, antiviral, antioxidant, and antimicrobial (Blunt et al. 2014, Radjasa et al. 2011, Senthilkumar and Kim 2013).

Antioxidants play an important role in biological systems, including cell signaling pathways and defense against oxidative damage. Intracellular antioxidant activity prevents damage 
caused by reactive oxygen species (ROS). While ROS are produced as a product of normal cellular functioning, excessive amounts can cause deleterious effects on DNA, RNA, and protein molecules, which, in theory, contribute to the physiology of aging and may be involved in many humans diseases, such as atherosclerosis, cancer, diabetes, and cardiovascular and neurological diseases, such as Parkinson's and Alzheimer's disease (Choudhari et al. 2014, Guetens et al. 2002).

Since multidrug resistance is a well-documented health problem, an important aspect of the search for natural compounds isolated from marine organisms is their antimicrobial activity (Al-Haj et al. 2010, Silva et al. 2013, Vieira et al. 2010).

Marine organisms are natural sources of diverse synthesized biocompounds that have specific protective functions against grazing, epiphytes and infections caused by microorganisms. The biological activity of these biocompounds may also have therapeutic applications of consequence to human health (Blunt et al. 2014, Radjasa et al. 2011, Senthilkumar and Kim 2013).

The zoanthid Palythoa caribaeorum (Duchassing and Michelotti, 1860) (Sphenopidae) is found in large quantities along the Ceará coastline where colonies form thick, encrusted mats on rocky substrates under shallow water. The skeleton is hard, while the outer surface is covered with large, round calyces surrounded by a low, rounded ridge, and the tissues are impregnated with sediment. Their development is vegetative with high rates of regeneration. During low tide, when they are exposed to the air, they produce a jelly-like substance that protects them from dryness (Rabelo et al. 2013, Soares et al. 2006).

Most bioactive substances isolated from the marine zoanthid of the genus Palythoa have been chemically classified as fatty acids, ceramides, steroids, or prostaglandins derived from glycerol and nitrogenous compounds (Almeida et al. 2012, Diop et al. 1986, Han et al. 2006, Pettit and
Fujji 1982, Shigemori et al. 1999, Uemura et al. 1979). Besides these classes of compounds, the vasoconstrictor palytoxin, a very complex molecule that presents both lipophilicity and hydrophilicity, was first isolated from the cnidarians zoanthid Palythoa toxica by Moore and Scheuer (1971). Later, this toxin was also found in other species of the same genus, such as $P$. caribaeorum (Ramos and Vasconcelos 2010).

This work aimed to evaluate the crude extract $(70 \% \mathrm{EtOH})$, and dichloromethane (DCM), ethyl acetate (EtOAc), and aqueous (Aq) fractions of the marine zoanthid $P$. caribaeorum at different concentrations $(12.5,25,50$, and $100 \mu \mathrm{g} \mathrm{mL}-1$ ) for total phenolic content (TPC), antioxidant, hemolytic and antimicrobial activities, as well as cytotoxicity using the brine shrimp (Artemia sp.) lethality bioassay.

\section{MATERIALS AND METHODS}

ANIMAL COLLECTION AND PREPARATION OF EXTRACT

The zoanthid specimens of Palythoa caribaeorum were collected in August 2013 at Paracuru Beach, São Gonçalo do Amarante, state of Ceará in northeastern Brazil, during low tide, under the authorization of SISBIO (No. 33913-1) given by the Instituto Brasileiro do Meio Ambiente e dos Recursos Naturais Renováveis. The specimens were transported to the Laboratório de Produtos Naturais Marinhos (PROMAR-LAB) of the Universidade Federal do Ceará (UFC) and washed with distilled water in order to remove all epiphytes.

Their identification was carried out by Professor Helena Matthews-Cascon (PhD). Voucher specimens were deposited at Coleção de Cnidario do Laboratório de Malacologia e Invertebrados Marinhos do Ceará (LINCE) of the Departamento de Biologia of the Universidade Federal do Ceará (UFC) under number 047.

Zoanthids in natura were lyophilized, ground and extracted with 70\% EtOH at 1:20 (w/v). 
Afterwards, two more re-extractions were carried out using the same solvent (Alencar et al. 2014). P. caribaeorum $70 \%$ EtOH crude extract was concentrated by reduced-pressure distillation, and then liquid-liquid partitioned with sequential elution with dichloromethane (DMC), ethyl acetate (EtOAc) and water (Aq).

\section{TOTAL PHENOLIC CONTENT (TPC)}

Total phenolic content of 70\% EtOH crude extract, as well as DMC, EtOAc and Aq fractions of $P$. caribaeorum at $1 \mathrm{mg} \mathrm{mL}^{-1}$, was determined using the Folin-Ciocalteu method (Kumar et al. 2008). Distilled water, Folin-Ciocalteu reagent and $20 \% \mathrm{Na}_{2} \mathrm{CO}_{3}$ were added to $200 \mu \mathrm{L}$ of samples. Following $30 \mathrm{~min}$ of incubation in the dark at room temperature, absorbance was measured at $760 \mathrm{~nm}$ using a microplate reader (Biochrom Asys UVM 340). The calculation of TPC was based on a previously generated gallic acid standard curve, and the results were expressed in $\mathrm{mg}$ gallic acid equivalent (GAE) $\mathrm{g}^{-1}$ of extract.

\section{DPPH RADICAL SCAVENGING ASSAY}

The DPPH scavenging activity of $70 \%$ EtOH crude extract and DMC, EtOAc and Aq fractions (12.5, 25, 50, and $100 \mu \mathrm{g} \mathrm{mL}^{-1}$ ) was measured according to the method described by Duan et al. (2006). The absorbance of sample, blank sample, and control was measured at $517 \mathrm{~nm}$, after $30 \mathrm{~min}$ incubation in the dark at room temperature, using a Biochrom Asys UVM340 microplate reader (Cambridge, UK). The sample consisted of a mixture of $1 \mathrm{~mL} \mathrm{DPPH}$ methanolic solution $(0.16 \mathrm{mM})$ with $1 \mathrm{~mL}$ of crude extract or fractions. The blank sample consisted of $2 \mathrm{~mL}$ of crude extract or fractions, while the control contained $2 \mathrm{~mL}$ DPPH methanolic solution $(0.16 \mathrm{mM})$ only. Butylated hydroxyanisole (BHA) was used as positive control. The percentage of DPPH scavenging activity was calculated using the expression below:
Scavening effect $(\%)=$

$\left[1-\frac{\left(\mathrm{Abs}_{\text {sample }}-\mathrm{Abs}_{\text {sample blank }}\right)}{\mathrm{Abs}_{\text {control }}}\right] \times 100 \%$

Eq. 1

Ferrous Ion Chelating (FIC) Assay

FIC of $70 \%$ EtOH crude extract and DMC, EtOAc and Aq fractions $\left(12.5,25,50\right.$, and $\left.100 \mu \mathrm{g} \mathrm{mL}^{-1}\right)$ was determined according to Wang et al. (2009). The absorbance of sample, blank sample and control was measured at $562 \mathrm{~nm}$ after $10 \mathrm{~min}$ incubation at room temperature, using a Biochrom Asys UVM340 microplate reader (Cambridge, UK). The sample consisted of distilled water, $2 \mathrm{mM}$ ferrous chloride $\left(\mathrm{FeCl}_{2}\right), 5 \mathrm{Mm}$ ferrozine and fractions at different concentrations. Distilled water was used for both blank sample and control, instead of ferrozine and fractions, respectively. Ethylenediaminetetraacetic acid (EDTA) was used as positive control. The percentage of the ferrous ion chelating activity was calculated using the expression below:

Ferrous ion chelating activity $(\%)=$

$$
\begin{gathered}
{\left[\mathrm{Abs}_{\text {control }}-\right.} \\
\frac{\left.\left(\mathrm{Abs}_{\text {sample }}-\mathrm{Abs}_{\text {sample blank }}\right)\right]}{\mathrm{Abs}_{\text {control }}} \times 100 \%
\end{gathered}
$$

Eq. 2

\section{FERRIC-REDUCING ANTIOXIDANT POWER (FRAP)}

The ferric-reducing antioxidant power of the $70 \%$ EtOH crude extract and DMC, EtOAc and Aq fractions $\left(12.5,25,50\right.$, and $\left.100 \mu \mathrm{g} \mathrm{mL}^{-1}\right)$ was determined using the method described by Ganesan et al. (2008). Initially, 0.2 M phosphate buffer ( $\mathrm{pH}$ 6.6) and $1 \%$ potassium ferricyanide were added to fractions at different concentrations. The mixture was then incubated at $50^{\circ} \mathrm{C}$ for $20 \mathrm{~min}$. After cooling, $10 \%$ trichloroacetic acid was added to the mixture. Next, an aliquot of the upper layer of the solution was mixed with distilled water and $0.1 \%$ ferric chloride. After $10 \mathrm{~min}$ incubation at room temperature, the absorbance was measured at $700 \mathrm{~nm}$ using a microplate reader (Biochrom Asys UVM 
340). BHA was used as positive control. Increased absorbance of the reaction mixture indicated increased reducing power.

\section{HEMOLYTIC ACTIVITY}

The hemolysis assay was determined according to Slowing et al. (2009) with some modifications. Human blood type A cells were obtained from Centro de Hematologia e Hemoterapia do Ceará (HEMOCE) and prepared by washing them six times with $50 \mathrm{Mm}$ Tris-HCl, $\mathrm{pH} 7.6$, containing $\mathrm{NaCl} 0.15 \mathrm{M}$ (TBS). Following the last wash, red blood cells (RBC) were diluted to $1 / 10$ of their volume with TBS. The assay was performed by mixing $0.3 \mathrm{~mL}$ of the $\mathrm{RBC}$ solution with $1.2 \mathrm{~mL}$ of $70 \% \mathrm{EtOH}$ crude extract and DMC, EtOAc and Aq fractions $\left(12.5,25,50\right.$, and $\left.100 \mu \mathrm{g} \mathrm{mL}^{-1}\right) ; 1.2 \mathrm{~mL}$ of distilled water was set as a positive control and $1.2 \mathrm{~mL}$ of TBS as a negative control. The mixtures were vortexed, left for $2 \mathrm{~h}$ at room temperature, and then centrifuged at $4,000 \times \mathrm{g}$ for $10 \mathrm{~min}$ at $4^{\circ} \mathrm{C}$. Absorbance of the supernatants was measured at $541 \mathrm{~nm}$ in a UV-Vis spectrophotometer. The percentage of hemolysis of each fraction was calculated using the expression below:

Hemolytic activity $=$

$\frac{A b s_{\text {sample }}-A b s_{\text {negative control }}}{\mathrm{Abs}_{\text {positive control }}-A b s_{\text {negative control }}} \times 100 \%$

Eq. 3

ANTIMICROBIAL ACTIVITY

All bacterial strains used in this study were supplied by the microbe bank of the Laboratório de Microbiologia Ambiental e do Pescado, Instituto de Ciências do Mar (UFC). The standard strains, including Staphylococcus aureus (ATCC 25923), Enterococcus faecales and Escherichia coli (ATCC 25922), and Salmonella enterica, Salmonella sp., were provided by the Instituto Oswaldo Cruz (IOC). Pseudomonas aeruginosa (ATCC 27853), Vibrio parahaemolyticus (ATCC 17802) and multiresistant $V$. parahaemolyticus were originally isolated from the hemolymph of the Pacific white shrimp Litopenaeus vannamei.

Sterilized $6 \mathrm{~mm}$ white disks were soaked with $100 \mu \mathrm{L}$ of $P$. caribaeorum $70 \%$ EtOH crude extract and DMC, EtOAc and Aq fractions at $100 \mu \mathrm{g} \mathrm{mL}^{-1}$ concentration. Control disks were also soaked with $100 \mu \mathrm{L}$ of each solvent. Each microorganism, at a concentration of $10^{8}$ cells $\mathrm{mL}^{-1}$, was inoculated on the surface of Mueller-Hinton agar plates in triplicate (CLSI 2012). Subsequently, disks soaked in samples were applied to the inoculated plates. A negative control disk soaked in solvent only, and a positive control disk soaked in $5 \mu \mathrm{g}$ ciprofloxacin, were used for each strain. The plates were incubated at $35^{\circ} \mathrm{C}$ for $24 \mathrm{~h}$. Inhibition halos $\geq 6 \mathrm{~mm}$ were considered evidence of antibacterial activity (Engel et al. 2006).

\section{ARTEMIA LETHALITY TEST}

The artemia lethality test was conducted according to Carneiro et al. (2013). The Artemia cysts were hatched in artificial seawater at $28^{\circ} \mathrm{C}$ under constant lighting and strong aeration. The cysts were incubated in a polyethylene cylindro-conical tube with $1 \mathrm{~g}$ cysts per liter of artificial seawater. This hatching condition mimics artemia's natural environment: shallow seawater. After a period of $48 \mathrm{~h}$, the aeration was halted, and the lighting was directed to the bottom of the hatching vessel. Based on their phototropic nature, nauplii migrate in the direction of the light to the bottom of the tube, while the unhatched cysts float. The nauplii are then collected and used for bioassays.

P. caribaeorum $70 \% \mathrm{EtOH}$ crude extract and fractions (DMC, EtOAc and Aq) were dissolved in artificial seawater at a concentration of $200 \mu \mathrm{g}$ $\mathrm{mL}^{-1}$. The assay was performed boarding 24-well Linbro plates in which each well contained 10 Artemia nauplii in a final volume of $2 \mathrm{~mL}$. Extract and fractions were added to the wells at final concentrations of $12.5,25,50$, and $100 \mu \mathrm{g} \mathrm{mL}^{-1}$. The experiments were performed in triplicate, and 
negative control wells contained $2 \mathrm{~mL}$ of artificial seawater with 10 Artemia nauplii. After 24 h, dead nauplii in each well were counted. From these data, the percentage of dead nauplii at each concentration and the $\mathrm{LC}_{50}$ value were calculated by probit analysis as described by Finney (1971).

\section{StATISTICAL ANALYSES}

All data are presented as mean \pm standard deviation. The mean values were calculated based on the data taken from three independent solutions of crude extract and fractions prepared on the same day. The results were submitted to one-way analysis of variance (ANOVA), followed by Tukey's HSD (Honestly Significant Difference) test in the case of null hypothesis rejection. The significance was defined at $p<0.05$.

The existence of statistically significant correlation between TPC and in vitro antioxidant activity of the samples was evaluated based Pearson's correlation coefficient, with TPC as the independent variable (x) and antioxidant activity in vitro as the dependent variable (y).

\section{RESULTS AND DISCUSSION}

TOTAL PHENOLIC CONTENT (TPC)

The existence of statistically significant correlation $(\mathrm{r}=0.9992, p<0.05)$ between absorbance at 760 $\mathrm{nm}$ and concentration of gallic acid (0.005 to $\left.0.05 \mathrm{mg} \mathrm{mL}^{-1}\right)$ made quantification possible $(\mathrm{y}=$ $0.0754+4.898, \mathrm{n}=8$ ). Values of TPC obtained from $P$. caribaeorum 70\% EtOH crude extract and DMC, EtOAc and Aq fractions at $1 \mathrm{mg} \mathrm{mL}^{-1}$ were quantified based on the gallic acid standard curve and are shown in Table I. The highest TPC values were observed in DCM fractions, followed by the $70 \% \mathrm{EtOH}$ crude extract and then the EtOAc and Aq fractions $(p<0.05)$.

Phenolic compounds possess a great diversity of structures holding at least one aromatic ring with one or more hydrogen atoms substituted by hydroxyl
TABLE I

Total phenolic content of the $\mathbf{7 0} \%$ EtOH crude extract and DMC, EtOAc and Aq fractions at $1 \mathrm{mg} \mathrm{mL}^{-1}$ of the marine zoanthid Palythoa caribaeorum.

\begin{tabular}{cc}
\hline Extract and fractions & TPC $\left(\mathrm{mg} \mathrm{GAE} \mathrm{g}^{-1}\right.$ extract $)$ \\
\hline $70 \%$ EtOH crude extract & $12.33 \pm 0.53^{\mathrm{b}}$ \\
DCM fraction & $18.17 \pm 0.62^{\mathrm{a}}$ \\
EtOAc fraction & $10.53 \pm 0.32^{\mathrm{c}}$ \\
Aqueous fraction & $3.18 \pm 0.14^{\mathrm{d}}$ \\
\hline
\end{tabular}

Values are the mean \pm standard deviation, $\mathrm{n}=3$.

Different lowercase letters - statistically significant difference $(p<0.05)$.

groups. They have the ability to scavenge free radicals, inhibit lipid peroxidation and chelate ferrous ion. These compounds are widely found in vegetables and microorganisms (Carvalho et al. 2010).

Recent studies report that the synthesis of biocompounds is generally associated with such microorganisms as bacteria, cyanobacteria and diatoms, which live in endosymbiosis with corals, nudibranchs and marine heterotrophic protists. It is believed that this biological interaction allows the development of heterotrophic organisms in nutrientpoor tropical seawater (Oliveira et al. 2013).

\section{ANTIOXIDANT ACTIVITY}

Antioxidant activity was determined by the DPPH radical scavenging, the ferrous ion chelating (FIC) and the ferric-reducing antioxidant power (FRAP) assays.

DPPH is commonly used as a free radical to evaluate antioxidant compounds capable of reducing DPPH by donating a hydrogen atom, thereby forming the non-radical DPPH-H (Cho et al. 2011). DPPH radical scavenging activity of both $70 \%$ EtOH crude extract and DMC, EtOAc and $\mathrm{Aq}$ fractions at all tested concentrations, varied from $53 \%$ to $62 \%$. Values of $\mathrm{IC}_{50}$ were 11.13 , $11.25,11.74$, and $11.28 \mu \mathrm{g} \mathrm{mL} \mathrm{m}^{-1}$, respectively. The positive control, BHA, showed activity from $90 \%$ to $97 \%$, corresponding to $\mathrm{IC}_{50}$ of $6.87 \mu \mathrm{g} \mathrm{mL}^{-1}$, which was significantly lower than the crude extract 
and fractions (Fig. 1). Although none of the analyzed samples showed higher results than BHA, the crude extract and fractions showed very satisfactory results, with values greater than $50 \%$ of inhibition of DPPH at the lowest concentration $\left(12.5 \mu \mathrm{g} \mathrm{mL}^{-1}\right)$.

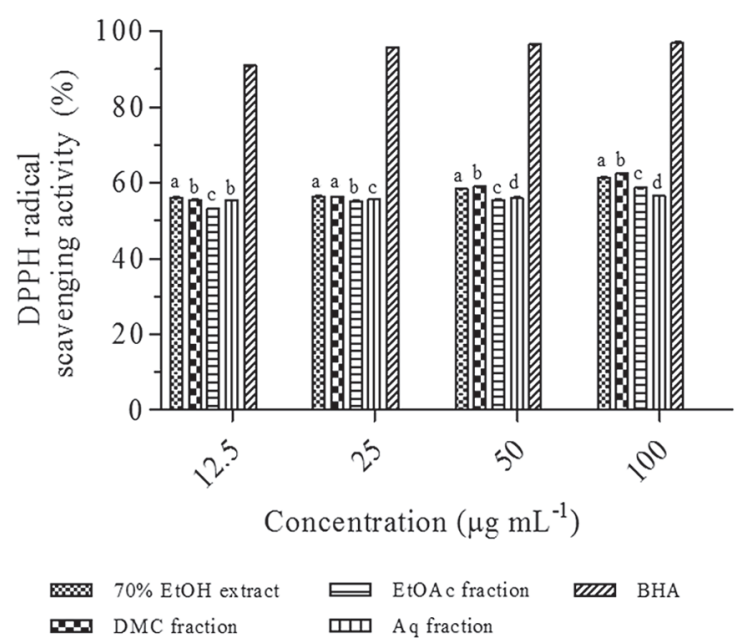

Figure 1 - Scavenging activity (\%) of DPPH of the 70\% EtOH crude extract and DMC, EtOAc and Aq fractions at different concentrations $\left(12.5,25,50\right.$ and $\left.100 \mu \mathrm{g} \mathrm{mL}^{-1}\right)$ of the marine zoanthid Palythoa caribaeorum and the positive control (BHA). Lowercase letters compare the 70\% EtOH crude extract and DMC, EtOAc and Aq fractions in the same concentration using one-way analysis of variance (ANOVA), followed by Tukey's HSD (Honestly Significant Difference). Same lowercase letters - no statistically significant difference $(p>0.05)$. Different lowercase letters - statistically significant difference $(p<0.05)$.

Additional statistical analysis revealed a significantly high correlation between DPPH radical scavenging activity and TPC $(r=0.941, p<0.001)$. The phenolic compounds are possibly the main source of the DPPH radical scavenging activity. Until now, however, no phenolic compound has been isolated from the zoanthid P. caribaeorum, making it plausible that associated microorganisms are responsible for the presence of such compounds, which are essential to their development. On the other hand, different compounds may be related to the ability of $70 \%$ EtOH crude extracts and DMC, EtOAc and Aq fractions to scavenge DPPH radical.
The ability of the antioxidant compounds to bind to metal ions was evaluated by FIC assay. The results are shown in Figure 2. For all tested concentrations, the $70 \% \mathrm{EtOH}$ crude extract displayed the highest FIC $\left(\mathrm{IC}_{50} 302.90 \mu \mathrm{g} \mathrm{mL}^{-1}\right)$, between $9.30 \%$ and $22.70 \%$, followed by EtOAc fraction $\left(\mathrm{IC}_{50} 457.77 \mu \mathrm{g} \mathrm{mL}^{-1}\right.$ ), between $4.60 \%$ and $13.53 \%$, Aq fraction $\left(\mathrm{IC}_{50} 547.91 \mu \mathrm{g} \mathrm{mL}^{-1}\right)$, from $3.48 \%$ to $10.43 \%$, and $\mathrm{DCM}$ fraction $\left(\mathrm{IC}_{50} 641.82\right.$ $\mu \mathrm{g} \mathrm{mL} \mathrm{m}^{-1}$ ), from $7.36 \%$ to $13.70 \%$. The positive control (EDTA) showed activity from $47 \%$ a $99 \%$, which was significantly greater than the crude extract and fractions $\left(\mathrm{IC}_{50} 13.20 \mu \mathrm{g} \mathrm{mL}^{-1}\right)$.

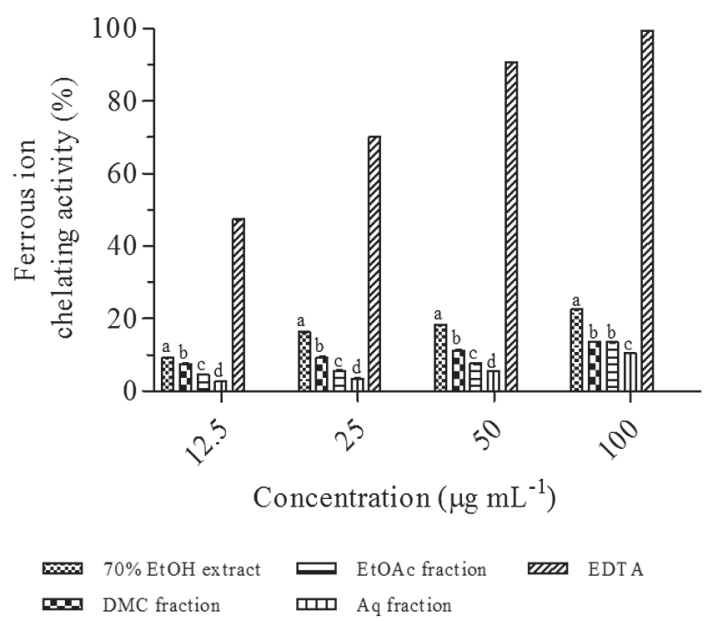

Figure 2 - Chelating ability (\%) of ferrous ion of the 70\% EtOH crude extract and DMC, EtOAc and Aq fractions at different concentrations $\left(12.5,25,50\right.$ and $\left.100 \mu \mathrm{g} \mathrm{mL}^{-1}\right)$ of the marine zoanthid Palythoa caribaeorum and positive control (EDTA). Lowercase letters compare the 70\% EtOH crude extract and DMC, EtOAc and Aq fractions at the same concentration using one-way analysis of variance (ANOVA), followed by Tukey's HSD (Honestly Significant Difference). Same lowercase letters - no statistically significant difference $(p>0.05)$. Different lowercase letters - statistically significant difference $(p<0.05)$.

A low correlation was observed between the chelating ability of ferrous ion and TPC $(\mathrm{r}=0.380$, $p<0.05)$, which may suggest that the phenolic compounds are not the main chelating agent. Other compounds in the crude extract and fractions, such as proteins and polysaccharides, are known for their 
ability to chelate metals. Such activity is evidenced by their inhibitory effect on the absorption of ferrous ions (Palmer et al. 2009, Vinayak et al. 2011).

Ferric-reducing power is an important indicator of the antioxidant potential of a compound or an extract. Thus, the $70 \% \mathrm{EtOH}$ crude extract and fractions of $P$. caribaeorum were evaluated by ferric reducing/antioxidant power assay to determine their ability to reduce $\mathrm{Fe}^{3+}$ to $\mathrm{Fe}^{2+}$. This ability indicates that the antioxidant compounds are electron donors and could reduce the oxidized intermediate of lipid peroxidation processes, thus acting as primary and secondary antioxidants (Vinayak et al. 2011).

The results of FRAP for the crude extract and fractions are shown in Figure 3. A slight increase in optical density can be observed for the crude extract and fractions as concentrations rise. No statistically significant difference was found between optical densities, except for the 50 and $100 \mu \mathrm{g} \mathrm{mL} \mathrm{m}^{-1}$ concentrations, which varied from 0.051 to 0.061 .

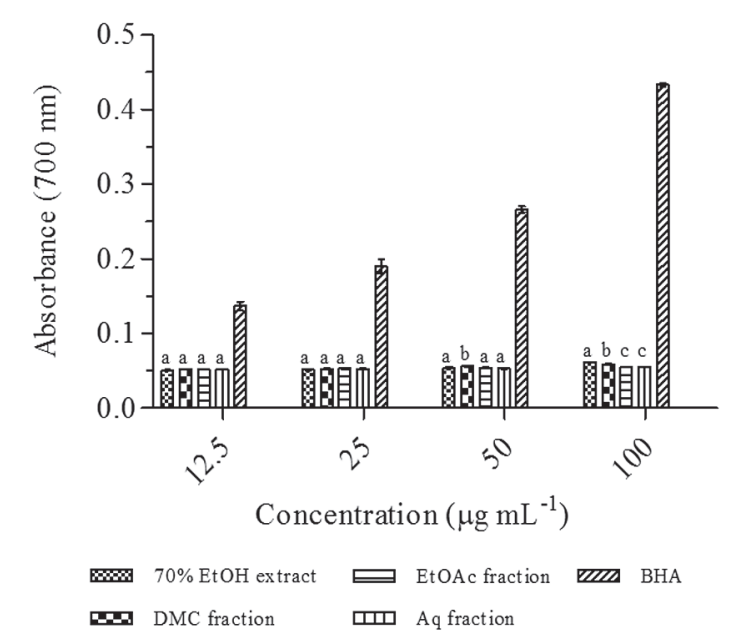

Figure 3 - Reducing power $\left(\mathrm{Abs}_{700 \mathrm{~nm}}\right)$ of the $70 \% \mathrm{EtOH}$ crude extract and DMC, EtOAc and Aq fractions at different concentrations $\left(12.5,25,50\right.$ and $\left.100 \mu \mathrm{g} \mathrm{mL}^{-1}\right)$ of the marine zoanthid Palythoa caribaeorum and positive control (BHA). Lowercase letters compare the $70 \% \mathrm{EtOH}$ crude extract and $\mathrm{DMC}, \mathrm{EtOAc}$ and $\mathrm{Aq}$ fractions at the same concentration using one-way analysis of variance (ANOVA), followed by Tukey's HSD (Honestly Significant Difference). Same lowercase letters - no statistically significant difference ( $p$ $>0.05)$. Different lowercase letters - statistically significant difference $(p<0.05)$.
Low correlation between ferric-reducing power and TPC was also observed $(\mathrm{r}=0.454$, $p<0.05)$ for $70 \%$ EtOH crude extract and DMC, EtOAc and Aq fractions at different concentrations $\left(12.5,25,50\right.$ and $\left.100 \mu \mathrm{gL}^{-1}\right)$. This may suggest that the phenolic compounds are not the main ferric-reducing agents.

\section{HEMOLYSIS ASSAY}

The hemolysis assay is useful to establish whether the cytotoxic activity is related to direct damage on the cell membrane or not. No hemolytic activity was seen when $70 \%$ EtOH crude extract and DCM, EtOAc and Aq fractions were tested with $0.15 \mathrm{M}$ $\mathrm{NaCl}$; phosphate buffer and distilled water were used as negative and positive controls, respectively.

Figure 4 shows the toxicity results for human erythrocytes treated with $70 \% \mathrm{EtOH}$ crude extract and DCM, EtOAc and Aq fractions. Weak hemolytic activity was detected for both EtOAc and Aq fractions, even at the highest concentrations, being $2.6 \%$ and $1.41 \%$, respectively. The crude extract and the DCM fraction also exhibited low hemolytic activity under $10 \%$ until a concentration of $50 \mu \mathrm{g} \mathrm{mL}^{-1}$ was reached. Then, from 50 to $100 \mu \mathrm{g} \mathrm{mL}^{-1}$, the activity increased considerably, indicating greater toxicity to the erythrocytes.

Wilke et al. (2010) found no lytic effect of $\alpha$-amino acids isolated from Protopalythoa variabilis on mouse erythrocytes after 1,2 , and $4 \mathrm{~h}$ treatment at the highest concentration tested $\left(200 \mu \mathrm{g} \mathrm{mL}^{-1}\right)$.

\section{ANTIMICROBIAL ACTIVITY}

The 70\% EtOH crude extract and DMC, EtOAc and $\mathrm{Aq}$ fractions at $100 \mu \mathrm{g} \mathrm{mL} \mathrm{m}^{-1}$ showed no antimicrobial activity against the tested bacterial models (data not shown). However, the negative results should be interpreted with caution based on the concentration of crude extract and fractions, as well as the diffusion characteristics of molecules in the culture medium. According to Muricy et al. (1993), apart from the analytic technique, it is also 


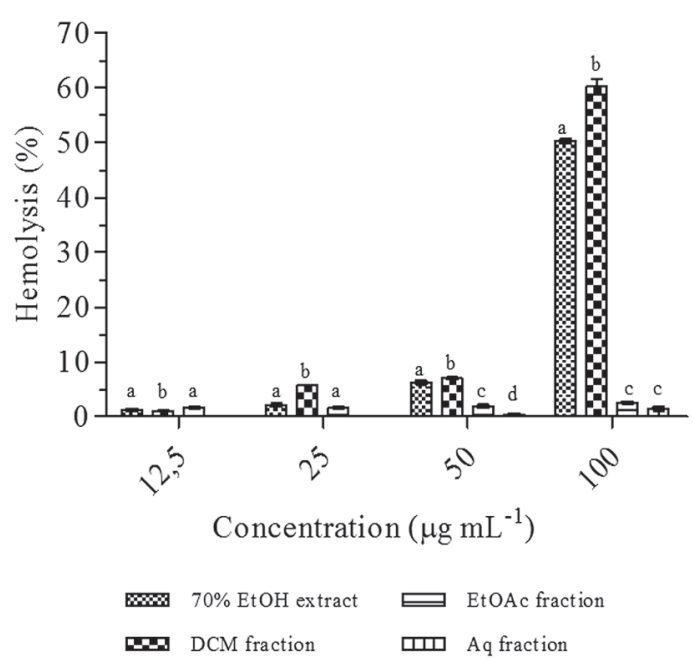

Figure 4 - Hemolytic activity of the $70 \% \mathrm{EtOH}$ crude extract and DMC, EtOAc and Aq fractions at different concentrations $\left(12.5,25,50\right.$ and $\left.100 \mu \mathrm{g} \mathrm{mL}^{-1}\right)$ of the marine zoanthid Palythoa caribaeorum. Lowercase letters compare the 70\% EtOH crude extract and DMC, EtOAc and Aq fractions in the same concentration using one-way analysis of variance (ANOVA), followed by Tukey's HSD (Honestly Significant Difference). Same lowercase letters - no statistically significant difference $(p>0.05)$. Different lowercase letters - statistically significant difference $(p<0.05)$.

important to consider such variables as individual, seasonal and microgeographic effects on the results of antimicrobial activity of natural extracts.

Artemia lethality TEST

The $70 \%$ EtOH crude extract and DMC, EtOAc and Aq fractions at all tested concentrations exhibited different levels of lethality against Artemia sp. nauplii. $\mathrm{LC}_{50}$ values are shown in Table II. The DCM fraction was the most toxic with an $\mathrm{LC}_{50}$ of $52.10 \mu \mathrm{g} \mathrm{mL}^{-1}$, whereas the least toxic was the Aq fraction with an $\mathrm{LC}_{50}$ of $117.45 \mu \mathrm{g} \mathrm{mL}^{-1}$.

Different marine invertebrates have been tested against Artemia sp., and it was observed that several of them were highly toxic to brine shrimp (Carballo et al. 2002, Thompson et al. 1985). Among those invertebrates, sea cucumbers presented a variety of biological activities with cytotoxic activity toward several cell lines and also toward brine shrimp by
TABLE II

Cytotoxic activity of the $\mathbf{7 0 \%}$ EtOH crude extract and DMC, EtOAc and Aq fractions at different concentrations $\left(12.5,25,50\right.$ and $\left.100 \mu \mathrm{g} \mathrm{mL}^{-1}\right)$ of the marine zoanthid Palythoa caribaeorum.

\begin{tabular}{c|c|c|c}
\hline $\begin{array}{c}\text { Crude extract } \\
\text { and fractions }\end{array}$ & $\begin{array}{c}\text { Concentration } \\
\left(\mu \mathrm{g} \mathrm{m}^{-1}\right)\end{array}$ & $\begin{array}{c}\text { \% Lethality } \\
24 \mathrm{~h}\end{array}$ & $\mathrm{LC}_{50} 24 \mathrm{~h}^{*}$ \\
\hline & 12.5 & 16.7 & \\
$70 \%$ EtOH & 25 & 23.3 & $83.06 \pm 11.04$ \\
crude extract & 50 & 30 & \\
& 100 & 60 & \\
\hline & 12.5 & 30 & \\
DCM fraction & 25 & 33.3 & $52.10 \pm 6.43$ \\
& 50 & 36.7 & \\
\hline \multirow{4}{*}{ EtOAc } & 100 & 90 & \\
fraction & 12.5 & 0 & \\
& 25 & 16.7 & $86.34 \pm 10.32$ \\
& 50 & 33.3 & \\
\hline & 100 & 56.7 & \\
Aq fraction & 12.5 & 10 & \\
& 25 & 10 & $117.45 \pm 11.87$ \\
& 50 & 23.3 & \\
\hline
\end{tabular}

* mean \pm standard deviation, $\mathrm{n}=3$.

secondary metabolites and proteins (Chludil et al. 2002, Muniain et al. 2008, Oda et al. 1997, Yamanishi et al. 2007). Some marine invertebrate extracts were tested for toxicity against Artemia sp., human lung carcinoma and human colon carcinoma (Carballo et al. 2002). The results indicated that extracts of sponges, cnidarians, echinoderms and tunicates exhibited toxicity against Artemia sp. and human carcinoma. Collectively, these findings indicated that the artemia lethality assay is useful for pretesting the toxicity of potentially biologically active molecules.

The high toxicity observed in the DCM fraction may be related to the presence of lowpolarity chemical compounds, such as fatty acids, ceramides and steroids (Almeida et al. 2012, Diop et al. 1986, Han et al. 2006, Pettit and Fujji 1982, Shigemori et al. 1999).

The brine shrimp assay implies an easy, inexpensive and rapid bioassay for testing cytotoxic activity of plant extracts and can be extrapolated for cell line toxicity and antitumor activity; as 
such, the artemia lethality test is very suitable for biotechnological purposes and the evaluation of bioactive compounds (Krishnaraju et al. 2005, Ullah et al. 2013).

Edrada et al. (1998, 2000) reported that the nonpolar compounds (diterpenes and sesquiterpenes) isolated from marine invertebrates, presented pronounced toxicity with $\mathrm{LC}_{50}$ less than $70 \mu \mathrm{g}$ $\mathrm{mL}^{-1}$ in the brine shrimp lethality test. This is an indication that they can be potentially active against cancer cells. The palytoxin, for instance, should have exhibited high toxicity at very low extract concentrations, but this did not happen. Görögh et al. (2013) observed very significant toxic effects on cancer cells using the palytoxin with an $\mathrm{LD}_{50}$ varying from 1.5 to $3.5 \mathrm{ng} \mathrm{mL}^{-1}$. Some authors do not agree on the biosynthetic origin of the palytoxin from the marine zoanthid, speculating a bacterial origin, apparently from Vibrio species and dinoflagellates of the Ostreopsis genus associated with marine sediments, which could possibly be incorporated in the tissues of this colonizing cnidarian during growth and development (Gandhi and Cherian 2000, Seemann et al. 2009, Soares et al. 2006).

\section{CONCLUSIONS}

The 70\% EtOH crude extract and DCM, EtOAc and Aq fractions of the marine zoanthid Palythoa caribaeorum presented antioxidant potential and cytotoxic activity against Artemia nauplii. They also showed low hemolytic activity against human erythrocytes at $50 \mu \mathrm{g} \mathrm{mL}^{-1}$. Thus, the extract and fractions possess biocompounds that can potentially be used as therapeutic agents, thus deserving studies that are more detailed for further isolation and evaluation.

\section{ACKNOWLEDGMENTS}

The authors would like to express their thanks for the grants and financial support received from the Conselho Nacional de Desenvolvimento Científico e Tecnológico (CNPq), Fundação Cearense de Apoio ao Desenvolvimento Científico e Tecnológico (FUNCAP) and Coordenação de Aperfeiçoamento de Pessoal de Nível Superior (CAPES) of the Brazilian Government. A.H. Sampaio, and R.H.S.F. Vieira are senior investigators of CNPq (Brazil). Additional thanks are given to Professor Helena Mathews-Cascon for helping with the identification of the marine zoanthid and to Mr. David Martin for helping with the English editing of the manuscript.

\section{RESUMO}

Os invertebrados marinhos são capazes de sintetizar compostos bioativos que podem ser benéficos à saúde humana. $\mathrm{O}$ objetivo desse estudo foi avaliar as atividades antioxidante, hemolítica, antimicrobiana e citotóxica do extrato bruto (EtOH 70\%) e frações em diclorometano (DMC), em acetato de etila (AcOEt) e aquosa (Aq) do zoantídeo marinho Palythoa caribaeorum. Os conteúdos fenólicos totais do extrato bruto e das frações DCM, AcOEt e Aq foram 12,33; 18,17; 10,53 e 3,18 mg AGE por grama, respectivamente. O sequestro do radical DPPH mostrou uma pequena variação. $\mathrm{O} \mathrm{IC}_{50}$ do extrato bruto e das frações DCM, AcOEt e Aq foram 11,13; 11,25; 11,74 e $11,28 \mathrm{~g} \mathrm{~mL}^{-1}$, respectivamente. Dentre as amostras, a habilidade de quelação foi maior no extrato bruto $\left(\mathrm{IC}_{50}\right.$ $\left.302,90 \mu \mathrm{g} \mathrm{mL}^{-1}\right)$, seguida pelas frações AcOEt, Aq e DCM com 457,77; 547,91 e 641,82 $\mu \mathrm{g} \mathrm{mL}^{-1}$, respectivamente. $\mathrm{O}$ poder de redução do ferro apresentou uma densidade óptica em torno de 0,5. As amostras testadas exibiram baixa atividade hemolítica, inferior a $10 \%$, até a concentração de $50 \mu \mathrm{g} \mathrm{mL}^{-1}$. Não foi observada atividade antimicrobiana para as cepas bacterianas testadas. Para a atividade citotóxica, $\mathrm{LC}_{50}$ de DCM, extrato bruto, AcOEt e Aq foram, respectivamente, 52,10; 83,06; 86,34 e $117,45 \mu \mathrm{g} \mathrm{mL}^{-1}$, mostrando elevada toxicidade.

Palavras-chave: atividade biológica, invertebrado marinho, produto natural, Sphenopidae.

\section{REFERENCES}

Al-Haj NA, Mashan NI, Shamsudin MN, Mohamed H, VAIRAPPAN CS AND SEKAWI Z. 2010. Antibacterial activity of marine source extracts against multidrug resistance organisms. Am J Pharma \& Toxicol 5: 95-102. 
ALENCAR DB ET AL. 2014. Antioxidant potential and cytotoxic activity of two red seaweeds species, Amansia multifida and Meristiella echinocarpa, from the coast of Northeastern Brazil. An Acad Bras Cienc 86: 251-263.

Almeida JGL, Maia AIV, Wilke DV, Silveira ER, BraZFilho R, La Clair JJ, Costa-Lotufo LV and Pessoa ODL. 2012. Palyosulfonoceramides A and B: Unique sulfonylated ceramides from the Brazilian zoanthids Palythoa caribaeorum and Protopalythoa variabilis. Mar Drugs 10: 2846-2860.

Blunt JW, Copp BR, Keyzers RA, MunRo MHG AND PRINSEP MR. 2014. Marine natural products. Nat Prod Rep 31: $160-258$.

Carballo JL, Hernández-Inda ZL, Perez P AND GarcíaGRÁVALOS MD. 2002. A comparison between two brine shrimp assays to detect in vitro cytotoxicity in marine natural products. BMC Biotechnol 2:1-5.

CARNEIRO RF ET AL. 2013. Halilectin 1 (H-1) and Halilectin 2 (H-2): two new lectins isolated from the marine sponge Haliclona caerulea. J Mol Recognit 26: 51-58.

Carvalho JCT, Gosmann G and Schenkel EP. 2010. Compostos fenólicos simples e heterosídeos. In: SIMÕES CMO, SCHENKEL EP, GOSMANN G, MELLO JCP, MENTZ LA AND PETROVICKY PR (Eds), Farmacognosia da planta ao medicamento, Porto Alegre: UFRGS editora, Porto Alegre, Brasil, p. 519-535.

Chludil HD, Muniain CC, Seldes AM and Maier MS. 2002. Cytotoxic and antifungal triterpene glycosides from the Patagonian sea cucumber Hemoiedema spectabilis. J Nat Prod 65: 860-865.

Cho ML, Lee HS, Kang IJ, Won MH and You G. 2011. Antioxidant properties of extract and fractions from Enteromorpha prolifera, a type of green seaweed. Food Chem 127: 999-1006.

Choudhari SK, Chaudhary M, Gadbail AR, Sharma A AND TEKADE S. 2014. Oxidative and antioxidative mechanisms in oral cancer and precancer: A review. Oral Oncol 50: 10-18.

CLSI - CliniCAL AND LABORATORY STANDARds InSTITUTE. 2012. Performance Standards for Antimicrobial Disk Susceptibility Tests; Approved Standard-Eleventh Edition. CLSI document M02-A11. Wayne, PA: Clinical and Laboratory Standards Institute 32(1): 76.

Diop M, LEUG-TACK D, BRAEKMAN JC AND KoRnPROBST JM. 1986. Sterol composition of four Zoanthidae members of the genus Palythoa from the Cape Verde Peninsula. Biochem Syst Ecol 14: 151-154.

DUAN XJ, ZHANG WW, LI XM AND WANG BG. 2006. Evaluation of antioxidant property of extract and fractions obtained from a red alga, Polysiphonia urceolata. Food Chem 95: 37-43.

Edrada RA, Proksch P, Wray V, Witte L and VAN OFWEGEN L. 1998. Four new bioactive lobane diterpenes of the soft coral Lobophytum pauciflorum from Mindoro, Philippines. J Nat Prod 61: 358-361.
EDRADA RA, Wray V, WitTE L, VAN OFWEGEN L AND PROKSCH P. 2000. Bioactive terpenes from the soft coral Heteroxenia sp. from Mindoro, Philippines. Z Naturforsch C 55: 82-86.

Engel S, Puglisi MP, Jensen PR AND FenicAl W. 2006. Antimicrobial activities of extracts from tropical Atlantic marine plants against marine pathogens and saprophytes. Mar Biol 149: 991-1002.

FINNEY DJ. 1971. Probit Analysis, $3^{\text {rd }}$ ed., University Press, Cambridge, UK.

GANDHI VM AND CHERIAN KM. 2000. Red cells haemolysis test as an in vitro approach for the assessment of toxicity of karanja oil. Toxicol In Vitro 14: 513-516.

GANESAN P, KUMAR CS AND BHASKAR N. 2008. Antioxidant properties of methanol extract and its solvent fractions obtained from selected Indian red seaweeds. Food Chem 99: 2717-2723.

GÖrÖGH T, BÈrESS L, QuABIUS ES, AMBrosch P AND HOFFMAN M. 2013. Head and neck cancer cells and xenografts are very sensitive to palytoxin: Decrease of c-jun n-terminale kinase-3 expression enhances palytoxin toxicity. Mol Cancer 12: 1-11.

Guetens G, Boeck G, Highley M, Van Oosteromand AT AND BRUJIN EA. 2002. Oxidative DNA damage: Biological significance and methods of analysis. Crit Rev Clin Lab Sci 39: 331-457.

Han C, Qi J, ShI X, SAKagami Y, Shibata T, UCHIDA K AND OJIKA M. 2006. Prostaglandins from a zoanthid: Paclitaxellike neurite-degenerating and microtubule-stabilizating activities. Biosci Biotech Biochem 70: 706-711.

KrishnaraJu AV, RaO TVN, SUndararaJU D, VANISREE M, TSAY HS AND SubBaraJu GV. 2005. Assessment of bioactivity of Indian medicinal plants using brine shrimp (Artemia salina) lethality assay. Int J Appl Sci Eng 3: 125-134.

Kumar KS, GANESAN K AND RAO PVS. 2008. Antioxidant potential of solvent extracts of Kappaphycus alvarezii (Doty) Doty - An edible seaweed. Food Chem 107: 289-295.

MOORE RE AND SCHEUER PJ. 1971. Palytoxin: A new marine toxin from a coelenterate. Science 172: 495-498.

Muniain C, Centurión R, Careaga VP and Maier MS. 2008. Chemical ecology and bioactivity of triterpene glycosides from the sea cucumber Psolus patagonicus (Dendrochirotida: Psolidae). J Mar Biol Assoc UK 88: 817-823.

Muricy G, Hajdu E, Araujo FV AND Hagler AN. 1993. Antimicrobial activity of Southwestern Atlantic shallowwater marine sponges (Porifera). Sci Mar 57: 427-432.

ODA T, TSURU M, HATAKEYAMA T, NAGATOMO H, MURAMATSU T AND YAMASAKI N. 1997. Temperature- and $\mathrm{pH}$ dependent cytotoxic effect of the hemolytic lectin CELIII from the marine invertebrate Cucumaria echinata on various cell lines. J Biochem 121: 560-567.

Oliveira FAS, Colares GB, Hissa DC, Angelim AL, Melo VMM AND LOTUFO TMC. 2013. Microbial epibionts of the colonial ascidians Didemnum galacteum and Cystodytes sp. Symbiosis 59: 57-63. 
PALMER CV, Modi CK AND Mydlarz LD. 2009. Coral fluorescent proteins as antioxidants. Plos One 4: 1-9.

PetTit GR AND FuJJI Y. 1982. Antineoplastic agents. 81. The glycerol ethers of Palythoa liscia. J Nat Prod 45: 640-643.

Rabelo EF, Soares MO AND Matthews-Cascon H. 2013. Competitive interactions among zoanthids (Cnidaria: Zoanthidae) in an intertidal zone of Northeastern Brazil. Braz J Oceanogr 61: 35-42.

Radjasa OK, VASKe YM, NaVArRo G, Vervoort HC, TENNEY K, LinInGTON RG And CREWs P. 2011. Highlights of marine invertebrate-derived biosynthetic products: Their biomedical potential and possible production by microbial associants. Bioorg Med Chem 19: 6658-6674.

RAMOS V AND VASCONCELOS V. 2010. Palytoxin and analogues: Biological and ecological effects. Mar Drugs 8: 2021-2037.

SeEmann P, Gernert C, Schmitt S, Mebs D And Hentschel U. 2009. Detection of hemolytic bacteria from Palythoa caribaeorum (Cnidaria, Zoantharia) using a novel palytoxinscreening assay. Anton Leeuw Int J G 96: 405-411.

SENTHILKUMAR K AND KIM SK. 2013. Marine invertebrate natural products for anti-inflammatory and chronic diseases. Evid-Based Compl Alt 2013: 1-10.

Shigemori H, SAto Y, Kagata T AND Kobayashi J. 1999. Palythoalones A and B, new ecdysteroids from the marine zoanthid Palythoa australiae. J Nat Prod 62: 372-374.

Silva GC, Costa RA, Peixoto JRO, NAscimento FEP, CARNEIRO PBM AND VIEIRA RHSF. 2013. Tropical Atlantic marine macroalgae with bioactivity against virulent and antibiotic resistant Vibrio. Lat Am J Aquat Res 41: 183-188.

SLOWING II, Wu CW, VIVERO-EsCOTO JL AND LIN VSY. 2009. Mesoporous silica nanoparticles for reducing hemolytic activity towards mammalian red blood cells. Small 5: 57-62.

SoAres ClS, Pérez CD, Maia MBS, Silva RS and Melo LFA. 2006. Avaliação da atividade anti-inflamatória e analgésica do extrato bruto hidroalcoólico do zoantídeo Palythoa caribaeorum (Duchassaing \& Michelotti, 1860). Rev Bras Farmacogn 16: 463-468.
THOMPSON JE, WALKER RP AND FAULKNER DJ. 1985. Screening and bioassays for biologically-active substances from forty marine sponge species from San Diego, USA. Mar Biol 88: 11-21.

Uemura D, Toya Y, Watanabe I And Hirata Y. 1979. Isolation and structures of two new pyrazines, palythazine and isopalythazine from Palythoa tuberculosa. Chem Lett 1979: 1481-1482.

Ullah MO, Haque M, URmi KF, ZULFIKER AHM, ANita ES, BEGUM M AND HAMID K. 2013. Anti-bacterial activity and brine shrimp lethality bioassay of methanolic extracts of fourteen different edible vegetables from Bangladesh. Asian Pac J Trop Biomed 3: 1-7.

Vieira GHF, Mourão JA, ÂNGelo AM, Costa RA AND VIEIRA RHSF. 2010. Antibacterial effect (in vitro) of Moringa oleifera and Annona muricata against Gram positive and Gram negative bacteria. Rev Inst Med Trop S Paulo 52: 129-132.

VinAYAK RC, SudHA SA AND ChATTERJI A. 2011. Bioscreening of a few green seaweeds from India for their cytotoxic and antioxidant potential. J Sci Food Agric 91: 2471-2476.

WANG T, JÓNSDÓTTIR R AND ÓlAFSDÓTTIR G. 2009. Total phenolic compounds, radical scavenging and metal chelation of extracts from Icelandic seaweeds. Food Chem 116: 240-248.

WILKE DV ET AL. 2010. Pro-apoptotic activity of lipidic $\alpha$-amino acids isolated from Protopalythoa variabilis. Bioorgan Med Chem 18: 7997-8004.

YAMANISHI T, YAMAMOTO Y, HATAKEYAMA T, YAMAGUCHI K AND ODA T. 2007. CEL-I, an invertebrate N-acetylgalactosamine-specific C-type lectin, induces TNF- $\alpha$ and G-CSF production by mouse macrophage cell line RAW264.7 cells. J Biochem 142: 587-595. 
